\title{
Forced And Early Marriages: Moral Failures Vs Religious Nuances
}

\author{
Bernard O. Itebiye, PhD \\ Adam Igbudu Christian Institute, Emevor, \\ (Affiliated to the University of Port-Harcourt) Nigeria
}

doi: 10.19044/esj.2016.v12n17p305 URL:http://dx.doi.org/10.19044/esj.2016.v12n17p305

\begin{abstract}
The rights of the child all over the world are considered to be very important. But forces and early marriages have become some of the ways the rights of children are being abused. This paper aimed at shedding more light on why children are victims of forced and early marriages and the effects and consequences of such marriages on the child and the society. The analyses employed Critical Discourse Analysis (CDA) framework. Data gathered both from the primary and secondary sources were analyzed through the hermeneutical, descriptive and analytical methods. The findings of this paper are that early and forced marriages have harmful developmental, psychological and physical consequences on the child; have negative effects on the society and the Nation at large; that scriptural assertions, in defense, are mere manipulative ideas to cover up moral failures; and that whatever reason is given for child marriage, the disastrous effects on the victims outweigh them and undoubtedly make child marriage a social evil. The paper concludes that early and forced marriages do exist in Nigeria and needs to be curbed and thereafter suggests strategies that will make for a better implementation of such laws to effectively curb forced and early marriages in Nigeria.
\end{abstract}

Keywords Used: Child, Forced, Marriage, Scriptures, Moral failures

\section{Introduction}

The pathetic story of the 13-year-old Ese Oruru, who was in August 2015, allegedly abducted in Opolo, Yenagoa Local Government Council of Bayelsa State; compelled and coerced to be converted to Islam and forcefully married by one Yunusa, who hails from Kano (Asomba 2016), has once again brought to the public purview, the malevolence of forced marriage and the need for further research on how it can be eliminated or curtailed. No doubt that the Biblical concept of Justice (Hebrew, צִדָקה) and equity 
(Hebrew, מִישָׁר) have been relegated and the law of the land made inactive as far as this issue is concern. According to Itebiye (2016), Justice and Equity are the hall mark of every society that operates under the rule of Law. When Justice, the revealed perfection of God's nature and infinite righteousness, which entails rendering to everyone that which is his or her due (Ottuh \& Itebiye, 2015); and the rule of law, which govern a given society (Nwogugu, 1996), are consigned into oblivious status over and above narcissistic intentions (Shryock, 2008), anarchy sets in.

The betrothal of female children to adult males has been and is still a regular occurrence in many places, especially among the Hausa-Fulani ethnic group of Northern Nigeria (Elizabeth, 2009) and, to a lesser extent, is prevalent also in other parts of the country (Braiman, 2014). In Northern Nigeria, child marriage is a traditional/cultural practice that is greatly influenced by Islam (Elizabeth, 2009). According to United Nations Population Fund (2013), about 48 per cent of Hausa-Fulani girls of Northern Nigeria are forced into marriage by age 15, while over 78 per cent are married by age 18. These appalling statistics led Elizabeth (2009) to describe the life of a girl child in Northern Nigeria as pathetic. To buttress her assertion she maintains that, while the ideal marriage age of women, though varies, is between 20 and 26 years old, in the Northern Nigeria, little girls who have started menstruating are considered mature for marriage. In some cases, a girl of 12years old can be given out for marriage based this premise (Braiman, 2013).

Despite the prevalence of child marriage in the country, child marriage is illegal in Nigeria. According to Akinwunmi (2010), Nigeria is one of the signatories of many international and regional instruments which regulate the rights of children. Nigeria ratified the Convention on the Rights of the Child (CRC) on 16 April 1991, and the African Charter on the Rights and Welfare of the Child (African Children's Charter) on 12 July 2001. Additionally, Nigeria took steps to domesticate both instruments in the form of the Child Rights Act (CRA). However, irrespective of Nigeria's passing of the CRA in 2003, child marriage is still being practiced. In other words, Nigeria as a country has continued to violate the provisions of CRC, the African Children's Charter and the CRA. In this paper, the issue is examined in other to proffer some kind of solution to the predicament, by arousing the interest of Nigerians and challenging the Nigerian Religious and State Leaders to re-examine the issue of forced and child marriage.

\section{Forced marriage}

According to Agbikimi (2015), marriage is a gift from God. He defines it as the "socially and ritually recognized union or legal contract between spouses that establish rights and obligations between them and their 
in-laws” (Agbikimi, 2015:128). Itebiye (2016) defines it as the legalizing of a relationship, to which the society gives its approval, between a man and a woman. In other words, the above definitions recognize marriage as a union.

Forced marriage, on the other hand, is seen not just as an abuse of God's gift but also of the human rights (Adeyemo, 2013). In his 2006 study on all forms of violence against women, the then United Nations Secretary General Kofi Annan, according to WLUML (2013), defined forced marriage as one that lacks the free and valid consent of at least one of the parties. He posits thus:

In its most extreme form, forced marriage can involve threatening behaviour, abduction, imprisonment, physical violence, rape and, in some cases, murder. There has been little research on this form of violence. (WLUML, 2013:6).

This agrees with the views of campaigners and advocates of women and children's right, who see force marriage as the absence of meaningful consent (Williamson, 2014) and assert that it constitutes gender based violence (Wallace, 1997), exploitation of women's vulnerability (Giyan, 2009), as well as a severe human rights abuse (WLUML, 2013).

\section{Early Marriage}

The most often used definition for early/child marriage is marriage that takes place under the age of 18 (Kyari \& Ayodele, 2014). The term "early marriage", therefore, is used to refer to both formal marriages and informal unions in which a girl lives with a partner as if married before the age of 18 (UNICEF 2005). In the same vein, UNIFPA (2006) defines early/child marriage as any marriage carried out before the girl is physically, physiologically, and psychologically ready to shoulder the responsibilities of marriage and childbearing. Child or early marriage, therefore, involves either one or both spouses being children and may take place with or without formal registration, and under civil, religious or customary laws, and involves minors who are deemed incapable of giving informed consent.

It is imperative to emphasize the differences between a forced marriage and an arranged marriage. They are not one and the same. In an arranged marriage, both spouses are free to choose whether or not they wish to accept the arrangement (Nwogugu, 1996; Otoo-Oyortey \& Pobi. 2003). In a forced marriage, this consent is lacking for one or both spouses.

\section{Why forced marriages happen}

According to Braiman (2014), one of the primary underlying reasons for child marriage is poverty. Quoting from the National Bureau of Statistics, Braiman (2014:481) asserted that the rate of poverty level in Nigeria put at "67.1 percent" whereas in "Northern Nigeria, the poverty level is 77.7 per 
cent in the North-West and 76.3 per cent in the North-East”. Poverty in the region undoubtedly encourages child marriage. According to Erulkar and Muthengi, child marriage is profitable to poor families in rural farming communities. In some cases, the betrothal of girls at a young age relieves parents of the costs and responsibilities of raising a girl.

The second reason asserted is the claim of morality and honour. According to Audi (2006), the desire to maintain "family honour" in terms of ensuring that young people marry into a particular, approved family or community, or to control unwanted behaviour in a child (such as perceived promiscuity) or to protect cultural or religious ideals which are misguided or out of date (Audi, 2006: 218). Braiman (2014) agrees and asserted that child marriage protects girls from social ills, such as promiscuity and to avoid dishonour and the shame attached to pre-marital sex, girls are married off before reaching puberty.

A third reason adduced for forced marriages is said to be the fear of homosexuality by parents. According to Audi (2006), homophobia is enough reason for parents to force a child or young person into a heterosexual marriage. In many cases, forced marriages are organized to maintain and strengthen family or community links (Giyan, 2009), or to ensure that land or assets remain within the family (Otoo-Oyortey \& Pobi, 2003). Forced marriages can also be motivated by immigration and citizenship purposes (Williamson, 2014), and organized to enable a family or community member living outside their own land to move back or remember their land of origin later in life (UNFPA, 2006).

\section{How forced marriage take place}

According to Adeyemo (2013), forced marriage often entails extreme pressure from family members. This can include physical and emotional violence. Emotional blackmail is common with families trying to coerce a victim by telling her that if she does not agree to marry the designated husband, she will be bringing shame on her family (An-Naim \& Howard, 2000). Families can also threaten to disown a victim, leave her without any parental support (financial and emotional), with no contact with siblings or other family members, and with nowhere to live (Audi, 2006). In some cases, families use religion as a means of coercing children and young people, saying that it is against their religion to refuse to marry (Braimah, 2014). Physical violence, in some extreme cases, is used as a means of coercing children and young people into forced marriage (Elizabeth, 2009). Children and young people can also be taken abroad to be married against their willin such cases, the victims are often tricked into going abroad and are not aware that they are being taken overseas to be forced into marrying someone. Sometimes, they may have no access to money, their return ticket or 
passport, and no one to talk to about their situation (Otoo-Oyortey, \& Pobi, 2003).

In other words, the victims are most time placed in situation where refusing to go ahead with a forced marriage can lead to severe consequences. In some cases they may be taken prisoner in their own home as their families may fear them talking about the attempted forced marriage if they meet up with others such as at school. In some rare cases, refusing a forced marriage can result in murder or so-called “honour killing” (Williamson, 2014).

\section{Consequences of Forced Marriage}

According to WLUML (2013), forced marriage is a global phenomenon but is most prevalent in Africa and Southern Asia. There are reported cases of forced marriage in developed Nations, like United Kingdom, but in most cases it involves South Asian families, Middle Eastern and African families (Williamson, 2014).

Forced marriage involving anyone under the age of 18 constitutes a form of child abuse (UNICEF 2005). According to Adeyemo (2013), a child who is forced into marriage is at risk of significant harm through physical, sexual or emotional abuse. In other words, forced marriage can have a negative impact on a child's health and development. Giyan, H. A. (2009), further posits that a child in such a situation would be absent from school resulting in the loss of educational opportunities, and possibly also future employment opportunities.

There are numerous detrimental consequences associated with forced marriage, and in particular, forced marriage involving children, including physical, developmental, psychological and social implications.

One serious consequence of forced marriage is physical abuse in the form of domestic violence and sexual abuse (An-Na'im \& Howard, 2000). According to WLUML (2013), women who marry younger are more likely to be physically abused by their spouses. In addition, anyone forced into a marriage faces a serious risk of rape or sexual abuse as they may not wish to consent, or may not be of legal age to consent to sexual relations (UNICEF, 2005). Young women forced into marriage may also face unwanted or enforced pregnancy and in many cases enforsced abortion (Otoo-Oyortey \& Pobi, 2003).

\section{Religious Nuances}

It is most unfortunate that despite the ills of forced and early marriage as highlighted above, some are finding scriptural excuses. Two Biblical passages have been said to have given allusion to permission or recommendation for forced or early marriage. They are: Numbers 31:17-18 and Ezekiel 16:7-8. 
(A) Numbers 31: 17-18

Now kill all the boys. And kill every woman who has slept with a man, but save for yourselves every girl who has never slept with a man. (NIV).

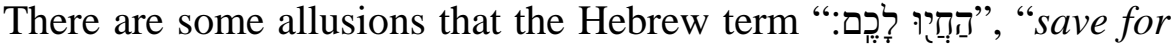
yourselves" (as interpreted by NIV) which could be properly translated as “keep alive for yourself” (as interpreted by KJV, NKJV, The Message, ESV, $\mathrm{CJB}$, etc) in the above passage, means that the warriors were given the express permission or even instructed by Moses to use their virgin (Hebrew,

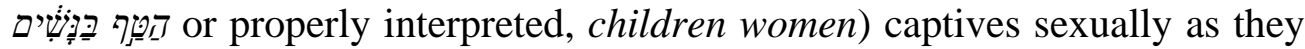
deem fit (Karim \& Misau, 2013).

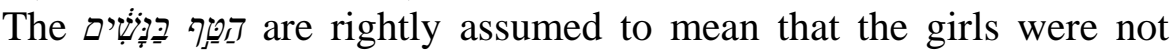
only unmarried but below puberty age. Professor Geza Vermes is said to have asserted that the Greek word "parthenos" also mean the same thing. In fact, in the Septuagint translation of the Old Testament, "parthenos" was used to render three distinct Hebrew words, Virgin, girl and young woman. Rabbis in the Tannaitic era (first to second century AD) were said to believe that virginity in a woman ceased with the physical onset of puberty. Rabbis were said to have debated whether bloodstains found after the wedding night in nuptial bed of a minor (virgin) is a mark of her first period or the consummation of the marriage (Karim \& Misau, 2013).

(B) Ezekiel 16:7-8:

"I made you flourish like a plant of the field. And you grew up and became tall and arrived at full adornment. Your breasts were formed, and your hair had grown; yet you were naked and bare. When I passed by you AGAIN and saw you, behold, you were at the age for love, and I spread the corner of my garment over you and covered your nakedness; I made my vow to you and entered into a covenant with you, declares the Lord GOD, and you became mine." (ESV)

Another Biblical passage commonly referred to as having allusion or prescription for child marriage is Ezekiel 16: 7-8. According to Karim \& Misau (2013), in the above passage God implies that the young virgins

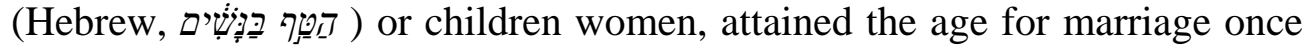
her breasts are formed and pubic hairs are noticed. He reasoned that: (a) the hair on the head of a girl grows many years before reaching the time of puberty, and (b) the connection to nakedness suggests that the exposure of her body parts needed to be covered since it was shameful for them to be exposed. In other words, there was no shame for the hair of a girl's head to be uncovered, but exposing her pubic hairs would be reprehensible.

The challenging questions that beg for answers in the above passages are: with reference to Numbers 31: 17-18, what war are we fighting and who 
are the Captives; and in reference to Ezekiel 16: 7-8, how does that particular text of the bible form a conclusion on marital age and statute?

Without doubt, the interpretation given to these two passages above could be one of the worst cases of eisegesis: the interpretation of a passage based on a subjective, non-analytical reading. Eisegesis is a mishandling of the text and often leads to a misinterpretation. Whereas, Exegesis (proper interpretation of Biblical text) is concerned with discovering the true meaning of the text, respecting its grammar, syntax, and setting; Eisegesis is concerned only with making a point, even at the expense of the meaning of words. The process of exegesis involves 1) observation: what does the passage say? 2) Interpretation: what does the passage mean? 3) Correlation: how does the passage relate to the rest of the Bible? And 4) Application: how should this passage affect my life?

Eisegesis, on the other hand, involves 1) Imagination: what idea do I want to present? 2) Exploration: what Scripture passage seems to fit with my idea? And 3) Application: what does my idea mean? Notice that, in eisegesis, there is no examination of the words of the text or their relationship to each other, no cross-referencing with related passages, and no real desire to understand the actual meaning. Scripture serves only as a prop to the interpreter's idea.

It should be noted that the Numbers $31: 17$ \& 18 is not a Biblical order or instruction on marriage, rather it is an injunction on how God's instructions should be obeyed - complete obedience. In the said passage, God instructed the Israelites to deal harshly with the Midianites: "Be hostile to the Midianites and strike them; for they have been hostile to you with their tricks, with which they have deceived you in the affair of Peor, and in the affair of Cozbi, the daughter of the leader of Midian, their sister who was slain on the day of the plague because of Peor," (Num. 25: 17 \& 18). But later, when Moses met the returning Israeli army, he saw that the order was not complied with. The Midianites, he said, should have died because they were directly culpable in Israel's sin at Baal of Peor. All, except the virgins, were then sentenced to death. This insured the extermination of the Midianites and to prevent the Israelites from being seduced into sin of adolatory.

According to Walvoord (1985), though this would have been a horrible thing for the virgins but their lives were spared and noted that in the culture of the people then, warfare and plunder was a necessary evil. But it should be noted that the virgins were spared because they obviously had had no role in the Baal of Peor incident that led the Israelites into disobeying God, nor do they by themselves have the capacity to do so in future. The young girls were spared, therefore, not to be mere instruments for masculinity but as a show of mercy. 
On the other hand, Ezekiel 16:7f cannot be referred to as God's definition of marital age or status, rather the passage is a reference to God's covenant with Israel. While verse 7 is particularly referring to the fact that God caused the Israelites to multiply exceedingly, in a miraculous fashion; verse 8 refers to the fact that the covenant God entered with Israel can be compared with the bond of marriage, as further explained in verses 11-13 (see also Gen.9:15, 16; Ex. 2:24; 6:5; Lev. 26: 42, 45; Psalms 106: 45; etc). God later referred to this covenant in verse 60 thus:

Yet I will remember the covenant I made with you in the days of your youth, and I will establish an everlasting covenant with you. (NIV)

\section{God's Word and Reason for Marital Relationship}

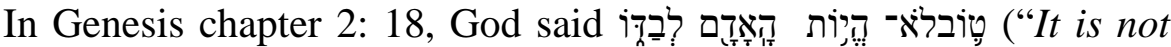
good for the man to be alone.”). Throughout chapter 1, God surveys His work and pronounces it good (Gen.1:10, 12, 18, 21, 25, 31). This is the first time God says that something in His creation is לאץ ("not good"). God's evaluation was that the man needed a human companion to correspond to him.

Therefore,

1. God designed marriage: He knows best how it should operate. His Word gives us the principles we need for satisfying marriages. Since God designed marriage, it takes three to make a good marriage: God, the man, and the woman. His idea is that הָָָזָָם (the man) should not be alone but have "a helper suitable for him" (2:18). The Hebrew word is not demeaning. It is often used of God's help for those in distress and for military assistance. It points to the fact that the husband needs and even depends on his wife's support and help.

\section{God designed marriage to meet our need for companionship:} "For this reason" means, Because of the way God designed marriage from the start, because the woman is bone of man's bone and flesh of his flesh, these things hold true. He shows that to fulfill our need for companionship, marriage must be a primary, permanent, exclusive, and intimate relationship. In other words, companionship in marriage requires that: (a) marriage must be primarily a relationship, (b) marriage relationship must be permanent, (c) marriage relationship must be exclusive and (d) marriage relationship must be intimate.

3. God designed marriage to provide an illustration of our relationship with Him: The Bible says that God created marriage for a purpose bigger than itself: Marriage is a picture of the believer's relationship with God. After discussing marriage and quoting Genesis 2:24, Paul writes, 
"This mystery is great; but I am speaking with reference to Christ and the church" (Eph. 5:32). Marriage is an earthly picture of the spiritual relationship that exists between Christ, the bridegroom, and the church, His bride. The consummation of a marriage is referred to in the Bible as a man knowing his wife; even so, we can know Christ our bridegroom. A husband and wife are one flesh; we are one spirit with the Lord (I Cor. 6:17).

\section{Conclusion}

The rights of the child anywhere in the world are important and should be protected. Forced and early marriages are some of the ways in which the rights of children are being exploited. This paper is of the view that the main under lining factor in the issue of forced and early marriages in Nigeria or anywhere else in the world is moral depravity and notes that there should be no religious or cultural justifications as it always constitutes a breach of human rights. Furthermore, this paper notes that whatever reasons are given as excuses for forced and early marriages, the disastrous effects on the victims outweigh them and undoubtedly make child marriage a social evil. This paper, therefore, posits that scriptural assertions in justification of forced and early marriages are mere manipulative ideas to cover up moral failures. Moreover, it is clear that the rights of the girl child in respect of marriage are not adequately protected by law.

\section{Recommendations}

Firstly, in order to protect the girl child from child marriage there is a need to enact a 'Prohibition of Child Marriage Act' which should deals broadly with the issue of child marriage. Such law should supersede religious and cultural adherences, and every religious and cultural practice that encourages child marriage should be sanction by law.

Secondly, the Nigerian government should see the failure to comply with its international and regional human rights obligations in the right perspective. As a signatory to the Convention on the Elimination of All Forms of Discrimination Against Women, CRC, the African Children's Charter and the African Women's Protocol, Nigeria is bound to uphold its contract for the protection of women, which includes the girl child. Therefore, for the Nigerian government to observe its treaty obligations in good faith, it must make a concerted effort to realize the implementation of the provisions pertaining to child rights in order to combat the adverse consequences of child marriage. 


\section{References:}

Adeyemo, O.O. (2013). Early and Forced Marriages in African System: An Appraisal of the Right of the Child in Nigeria. In Nigerian Journal Family Practice. 4 (2). Pp. 27-33

Agbikimi, N.A (2015). “An Exegetico-Theological Interpretation of Genesis 2:23-24 and Its Implication for Christian Marriage. In Niger Delta Journal of Religious Studies. 2 (1). Pp. 122-134.

Ajumobi, F. (2014). Nigeria and the ills of child marriage. http://www.vanguardngr.com. Retrieved from Vanguaronline of May 25, 2014.

Akinwunmi O.S. (2010). Legal impediments on the practical implementation of the Child Right Act 2003. International Journal of Legal Information. 37(3). Pp. 386-396.

An-Na'im, A. \& Howard, C. (2000). Forced Marriage. https://www.soas.ac.uk/honourcrimes/resources/file55689.pdf. Retrieved from SOAS, University of London.

Ango, R. G.(1991): “The. Impact of Girls’ Education on Early Marriage”, Independent Evaluation Report: CAMIFED and CAMA

Asomba, I. (2016). Free Ese: Outrage over alleged abduction, forceful marriage of 14-yr-old in Kano. http://www.vanguardngr.com/2016/02/freeese-outrage-over-allegedabduction-forceful-marriage-of-14-yr-old-in-kano/

Audi, J.A.M. (2006). Child Custody (Hadanah) Under Islamic Law in Nigeria; looking at the Best Interest of the Child. In Journal of Private and Comparative Law. 1(1): Pp. 216-232

Braimah, T. S. (2014). Child marriage in Northern Nigeria: Section 61 of Part I of the 1999 Constitution and the protection of children against child marriage. In African Human Rights Law Journal. 14 (2). Pp. 474-488.

Bamgbose, O. (2002). Customary Law Practices and Violence against Women: The Position Under the Nigerian Legal System .[Presentation] 8th International Interdisciplinary Congress on Women, Department of Women and Gender Studies, University of Makerere.

Blood, R.O. (2009). Marriage Culture and The Christian Home. London: Collier-Macmillan Ltd.

Clark, S. (2006): Protecting young women from HIV/AIDS: The case against child and adolescent marriage. International Family Planning Perspectives, 32(2), 79-88.

Elizabeth, E (2009). Child marriage: An undying culture? http://www.thetidenewsonline.com/2009/12/28/child-marriage-an-undyingculture. Retrieved from The Tide online of Thursday, April 07, 2016.

Ferguson, C. (2014). Love, Courtship and Marriage. Bloomington: Authorhouse Publishing 
Gilbertson, J. (2006). PC Study Bible V5.0C for Windows. www.biblesoft.com

Giyan, H. A. (2009): Women and Education: Equity and Equality. Berkley: McButcheonHasel, G.F. (1991). Old Testament Theology: Basic Issues in the Current Debate. Grand Rapids, Michigan: William B. Eerdmans Publishing Company.

Hornby, A.S. (2000). Oxford Advanced Learner's Dictionary of Current English. Oxford: University Press.

Ige, T. \& Lewis, O.(1999). Human rights made easy. ${ }^{\text {rd }}$ Edn. Lagos: Legal Research and Resource Development Centre.

International Bible Society (1984). The Holy Bible (New International Version). Oxford: Biblica.

Itebiye, B. O. (2015). Managing Anger In The Niger Delta of Nigeria: Old Testament Approach. In AICI Journal of Religious Studies and Theology. 1 (1). Pp. 29-37.

-------(2016). An Exegetical Analysis Of Numbers 31: 27 As A Panacea For Resource Control Agitation In Niger Delta. In European Scientific Journal April 2016 ed. 12 (11). Pp 170-182

(2016). Courtship In Christian Marriage: A Biblical Insight. In AICI Journal of Religious Studies and Theology. 2 (1). Pp. 19-28.

Karim, K. \& Misau, A.M. (2013). Bible: Does Numbers 31:18 Sanction PrePubescent Marriages (Child Marriage). http://discover-thetruth.com/2013/11/14/bible-does-numbers-3118-sanction-pre-pubescentmarriages. Retieved from Discover The Truth of November 14, 2013 Kyari, G. V. \& Ayodele, J. (2014). The Socio-Economic Effect of Early Marriage in North Western Nigeria. In Mediterranean Journal of Social Sciences. 5 (14). Pp.582-592.

Kore, D. (1970). Personal Adjustment, Marriage and Family Living. New Jersey: Prentice-Hall, Inc.

Mbachu, C.A.E. (1996). Enrichment for an Ideal Marriage. Enugu: Snaap Press Ltd.

Nwobi, P.C. (1997). Marriage and Family Counseling. Enugu: PAN-AFRIC Publishers.

Nwogugu, E.I. (1996). Family Law in Nigeria. Revised ed. Ibadan: Claverianum Press;

Nwonu, C. O. (2014). Nigeria and Child Marriage: Legal Issues, Complications, Implications,

Prospects and Solutions. In Journal of Law, Policy and Globalization . Vol. 29. Pp. 120-126

Otoo-Oyortey, N. \& Pobi, S. (2003), "Early Marriage and Poverty: Exploring links for policy and program development. The Forum on 
Marriage and the Rights of Women and Girls in collaboration with the International Planned Parenthood Federation.

Ottuh, J.A. \& Itebiye, B.O. (2015). Economic Injustice in Nigeria (Acts 2:44-45): The Niger Delta Experience. In Canadian Social Science. 11 (10). Pp. 23-31

Shryock, H. (2008). Happiness for Husbands and Wives. Washington: Review and Herald Publishing Ass.

Strong, J. (1995). The New Strong's Exhaustive Concordance of The Bible. Nashville, Tennessee: Thomas Nelson, Inc.

The Bible League (2006). The Topical Study Bible $2^{\text {nd }} E d$. Chicago: Tyndale Publisher

The Parallel Bible Hebrew-English Old Testament with Biblia Hebriaca Leningracia (2003). Peabody, Massachusetts: Hendrickson Publishers

The United Bible Societies (1994). Good News Bible, $2^{\text {nd }}$ Ed. Nairobi. The United Bible Societies, Africa Inter-Regional Services

UNICEF (2010): “Child Marriage Advocacy Program: Fact Sheet on Child Marriage and Early Union

UNICEF (2005): Early Marriage: A Harmful Traditional Practice. UNICEF: New York, USA. www.unicef.org/childmarriage

UNICEF (2004), “Child Marriage Advocacy Program: Fact Sheet on Child Marriage and Early Union

UNICEF (2003): Early Marriage: Whose Right to Choose? Mission Statement of the Forum on Marriage and the Rights of Women and Girls.UK.

UNICEF (2001): "Early Marriage: Child Spouses”, Accessed on 8th August, 2013 www.unicef.org/childmarriage,

UNICEF (1994): “Child Marriage Advocacy Program: Fact Sheet on Child Marriage and Early Union

UNFPA. (2006): "In ending child marriage, A guide for global policy action International Planned Parenthood Federation and the Forum on Marriage and the Rights of Women and Girls. U.K.

United Nations Population Fund (2013). 'Early marriage in Nigeria' http://nigeria.unfpa.org/nigeirachild.html.

Wallace, R. (1997). International Human Rights, Text and Materials. London: Sweet and Maxwell.

Walvoord, J .F. (1985). The Bible Knowledge Commentary Num 31:13. Wheaton, IL: Victor Books.

Women Living Under Muslim Laws (WLUML). (2013). Child, Early and Forced Marriage: A Multi-Country Study. www.wluml.org/sites/wluml.org/files/UN\%20report\%20final.pdf.

A Submission to the UN Office of the High Commissioner on Human Rights (OCHCR) 15 December 2013. 
Williamson, J. (2014). Child Marriage: Causes, Effects and Interventions. www.givingwhatwecan.org/sites/givingwhatwecan.org/files/attachments/chil dmarriage-causeseffectsandinterventions.pdf. Retrieved from Giving What We Can.

Youngblood, R.E. et al. ed (1995). Nelson's New Illustrated Bible Dictionary. Nashville, Tennessee: Thomas Nelson Publishers. 